\title{
Transnational Education: A Case Study of One Professional Doctorate
}

\author{
Marnie O’Neill
}

Correspondence: Marnie O’Neill, Graduate School of Education, University of Western Australia, 35 Stirling Highway, Crawley, 6009, Australia. Tel: 61-8-6488-2392. E-mail: Marnie.ONeill@uwa.edu.au

Received: August 6, 2012 Accepted: August 30, 2012 Online Published: November 28, 2012

doi:10.5539/hes.v2n4p14 URL: http://dx.doi.org/10.5539/hes.v2n4p14

\begin{abstract}
This case study of a Doctor of Education program in a transnational setting is contextualized in Australian national policies for international higher education and influences of regionalization and globalization. The doctorate was designed to meet aspirations of professional practitioners in Australia and South East Asia where the School had productive partnerships. The longitudinal case study discusses factors influencing revision of the program in response to federal government policies, student feedback over two reviews and considerations of quality delivery in the transnational setting. Finally, it presents an analysis of the perceived current success of the program and threats to its future viability.
\end{abstract}

Keywords: Doctor of Education, professional doctorate, transnational education, regionalization, globalization

\section{Introduction}

This paper provides a retrospective account of one Australian university offering a professional Doctorate in Education (EdD) in domestic and transnational settings. It is therefore located in the wider context of international/transnational education (Waters \& Brooks, 2011). Although Yang (2002) suggests for universities a culturally oriented approach to internationalization that focuses on

...awareness and operation of interactions within and between cultures through its teaching, research and service functions, with the ultimate aim of achieving mutual understanding across cultural borders (p. 83),

as Waters and Brooks note, "international students are increasingly being seen as a panacea for universities, faced with substantial cuts in government funding - and this view pertains not just to the United Kingdom but elsewhere" (p. 155). Lewis (2011) observed that marketing and branding of international education in New Zealand had become "big business"; Marginson (2002, p. 284) noted that "the neo-liberal pattern is to reduce state subsidization of higher education, shift costs to 'the market' and consumers, demand accountability for performance, and emphasize higher education's role in the economy." Australia has been no exception to this trend. Harmon (2005) recognized that Australia had become the third largest exporter of higher education services internationally, with international students comprising well over $20 \%$ of total student enrolments in Australian universities, producing substantial financial benefits and export income.

Caution about over-reliance on international income was expressed by some universities: "These benefits have led many Australian universities to pursue a policy of almost unconsidered expansion of international student numbers" (The University of Sydney, 2011, p. 16.). By 2011, this caution seemed well-founded. Lower onshore enrollments in all sectors other than Higher Education (HE) contributed to a decrease of 8.9\% on 2010 figures to approximate the 2008 levels. The HE sector recorded only a slight increase $(0.1 \%)$. Exposure of universities to shifts in the market was recognized by the University of Sydney:

....an increased reliance on international student fee income has arguably left the Australian university sector excessively vulnerable to the increasing competition for high-quality international students....Perhaps the most significant long-term threat is increasing competition in this market, where Australia, if it were to fall behind its competitors in the provision of outstanding research training, excellent teaching, good support services or accommodation, might face a decline in its market share. (The University of Sydney, 2011, p. 17)

Protection of the reputation of Australian universities was part of the agenda of the Australian Universities Quality Audit (AUQA). AUQA (Stella \& Liston, 2008) adopted Knight's definition of internationalization as "the process of integrating an intentional, intercultural or global dimension into the purpose, functions and 
delivery of post-secondary education" (Knight, 2004, 2008). This paper focuses on transnational provision of the Doctor of Education (EdD) by one Australian university. Congruent with the AUQA definition, the transnational programs offered by the School in this study are categorized as "Australian university programs being taught offshore wholly by university staff" (Stella \& Liston, 2008, p. 30).

Australian universities' engagement in offshore or transnational programs had two main drivers: broadening their sources of revenue (especially as the Commonwealth financial contribution reduced), and enhancing their international reputations (Davis, Olsen, \& Bohm, 2000). Transnational programs did not emerge as a force until the mid 1990s (Tootell, 1999), after which expansion was rapid and consistent. Transnational enrolments appeared to peak at 73,000 in 2004 (DEST, 2004, p.1), declining in subsequent years (Banks \& Kevatt, 2009), before trending upward to 76446 in 2010 (Ziguras, 2011). Quality in provision of international and transnational programs is governed at the federal level by two key documents that comprise the regulatory framework - the Education Services for Overseas Students (ESOS) Act 2000 (amended, 2011) and The National Code of Practice for Registration Authorities and Providers of Education and Training to Overseas Students (The Australian National Code).

\section{Specific Context of the Case Study}

The case study School constitutes a small single school faculty of education in a midsize comprehensive Australian university. Until 1999, when an undergraduate teacher education program commenced, it offered a graduate diploma in secondary (pre-service) teacher education, together with postgraduate masters and doctoral degrees, predominantly undertaken in part-time enrolments by mature aged students in full time employment. Only small numbers of domestic students and even fewer international postgraduate students could afford fulltime postgraduate study.

\subsection{School Impetus for Transnational Programs}

Financial insolvency was the primary impetus for commencing transnational programs; a School Review in 1994 indicated that the School was no longer financially viable. The onshore programs described above generated insufficient income to cover costs of delivery, particularly the professional experience components of the pre-service teacher education programs; federal constraints on duplicate programs offered by universities in the same jurisdiction left little room for onshore expansion. From 1997, transnational agreements provided Masters degrees by coursework and major paper, mirroring onshore courses and exploiting economies of whole class teaching, as only the major paper required any individualized tuition. Lecturers who normally taught the courses onshore delivered courses in compressed mode, either in the evenings or as full day weekend workshops. Contracts negotiated with four partners offshore explicitly required face-to-face delivery by School staff.

Partnerships specified different terms according to the services provided by each partner, ranging across marketing, recruitment, provision of infrastructure support, reproduction of teaching materials, support for students and collection and dispatch of student assignments. Australian providers may set fees according to the market, rather than charging the fee set by the university for full-time international students onshore. The differential, together with the advantages of maintaining employment and residence in the home country, as opposed to income foregone and residential expenses incurred in onshore programs, enhances the attraction of the transnational option. Partnership agreements signed off by the university as the responsible entity, rather than individual schools, tended to fix financial agreements for three years. Financial risks include failure to maintain sufficient enrolments to cover costs; responsibility for "finishing" small numbers of students at the end of an agreement; unpredicted cost increases during the course of an agreement; significant changes in relative currency values.

The success of students completing the Masters programs increased pressure from two partners in Singapore and one in Hong Kong to offer the Doctor of Education. School program coordinators were reluctant to do so until clear academic and financial viability in the transnational context was established. Enrolments at all sites were to be managed on a cohort basis, rather than on a "rolling" basis to maintain financial viability, especially during the thesis phase.

\subsection{Design of the EdD Program in the Case Study School}

The EdD was among the first professional doctorates approved by the University in 1993. The approval process was stringent; Academic Council required that the program maintained academic standards and rigor associated with the $\mathrm{PhD}$, so that the $\mathrm{EdD}$ was seen to be of similar quality, but different in structure. The $\mathrm{PhD}$ was a research-only degree with no coursework support; students were expected to be "research ready" on the basis of meeting the admission requirements. $\mathrm{PhD}$ admission hinged on demonstrated research preparation through either 
a Bachelor's degree with first or upper second class honors, a Master's degree with a research component, or demonstrated research preparation (undefined); admission to the EdD additionally required the equivalent of two years of full time professional experience. Initially, the EdD was modeled on a US professional doctorate, focusing on Educational Administration. Students completed five coursework units (including a content driven units related to educational administration and management), the research seminar and an oral examination across the range of content material covered in the program, before successfully defending their research proposal and completing a thesis of 70,000 words. Consistent with the PhD procedures, theses were examined by three independent, external examiners. This structure conformed to Maxwell and Shanahan's (1997) definition of a first generation professional doctorate, preparing prospective administrators and leaders of the profession.

\subsection{Program Review}

The 1999 program review had two drivers: part-time students should have completed in the preceding year; pressure to offer the program transnationally was growing. Although within the allowable time-frame for part-time enrolment, onshore completion rates were disturbingly slow: one in 1997and five in 1999. All students enrolled in the onshore program were surveyed, and focus group interviews were organized for those able to attend. Feedback indicated that:

- course work did not provide a sufficient focus on research training;

- progression was too slow due to the requirements of coursework units, seminars and oral examinations;

- the oral examination had little function other than inducing extreme stress; it served no assessable function, because it was not constituted as an assessable unit;

- course work content papers frequently had little relevance to the final research project.

Students regarded the focus on Educational Administration as too narrow, identifying curriculum development and implementation, teaching and learning, professional development and career pathways, policy studies and home schooling as appropriate research topics for professional doctorates. Students frequently entered the program with little idea of the research that they planned to pursue; some unfortunately had no clearer idea at the end of the course work. Casualties of this experience left the program with no recognition of their achievements in the coursework phase. Clearly, the existing structure was unsatisfactory for onshore students, and inappropriate to the transnational setting.

Fragmentation of course offerings to provide content-driven units across a broader range of fields was economically unsound, and the advantages of membership of a cohort of research colleagues would be lost. The emerging emphasis from the Department of Education, Science and Training (DEST) on postgraduate studies as Research Training Schemes (RTS) suggested that the course revisions should emphasize skills and competencies required to conduct research, rather than substantive content units. Recognition of doctoral programs for RTS status, attracting federal funding for students required a 2:1 ratio of research to coursework. Market research with prospective and current onshore students indicated that one reason for choosing the program was access to training and support as mature-aged re-entry students who lacked confidence in their capacity to undertake research. Expressed demand from all three offshore partners indicated concern about the status of the EdD relative to the $\mathrm{PhD}$ as an acceptable qualification for academic positions in universities. In sum, these factors strongly supported program revision to provide systematic research training for mature professionals returning to study in an applied field. Students in the first review identified two main desires:

- improvement of their professional status and career marketability; and

- "real research" which translated into an expectation that their doctoral qualification would be recognized as a research degree, and that their research would be on a topic congruent with their professional interests.

Market research with prospective transnational candidates revealed considerable anxiety about the quality of supervisory support at the thesis stage. Some applicants described themselves as "refugees" from other transnational programs in which they had felt like "orphans" at the thesis stage, with very little support, but the requirement to pay fees whether or not they made discernible progress.

The information generated from the course review and the market research identified three criteria on which the EdD Coordinators were intransigent-

- $\quad$ streamlined taught courses to provide focused research training and adequate support to students;

- flexibility to accommodate students' individual research topics; and

- supervisory support to enhance students' confidence that they would complete the thesis successfully.

Furthermore, the program had to comply with Australian government quality requirements and Level 10 
(doctoral) of the Australian Qualifications Framework, in an economic delivery which allowed the School to set market-competitive fees and maintain an acceptable profit margin.

\subsection{Program Restructure}

The restructure was designed to meet RTS requirements. Units were reduced to four, explicitly focused on research knowledge and competencies, conceptualized as a Brunerian spiral, allowing for progressive re-focusing of proposed research topics as students proceeded through the course work units. Three units covered advanced methods of research; conceptual, contextual and empirical literature in the field; research design, and the implications of design decisions; and the fourth unit returned to the issues of research methodology and ethics in preparing a research proposal. Each unit was assessed by an 8,000 word paper. Coursework was explicitly directed to providing experienced practitioners returning to academic study with critical skills as research consumers, knowledge and competence in research inquiry, and skills of argument in academic writing. Deeper knowledge in the selected content fields was targeted by conceptual, contextual and empirical literature reviews and in development of research proposals, rather than content driven course units. Despite the necessarily generic nature of the program design, the underlying intent and the delivery in small classes resonates with the principles of teaching of the Carnegie Project on the Educational Doctorate (CPED):

- Teaching is deliberate, pervasive and persistent. It challenges assumptions, engages in action and requires ongoing assessment and accountability

- Teaching and learning are grounded in theory, research, and in problems in practice. It leads to habits of mind, hand and heart that can and will be applied to authentic professional settings

- Teaching helps students develop a critical and professional stance with a moral and ethical imperative for equity and social justice. (CPED, 2012a.)

This program design might be considered very conservative, differing little from conventional approaches to doctoral study. Certainly, it does not meet criteria identified by Lee, Green and Brennan (2004, p. 124), for Mode 2 or second generation doctorates. A major change required candidates to identify a research topic (broadly) before enrollment, and to refine this topic throughout the coursework, applying the generic teaching to develop their topic in coursework papers. Based on survey feedback, onshore students were interviewed during the application phase; proposed research topics were discussed in detail, to ensure viability, that supervision could be provided, and that the student was in a position to carry out the research. All papers were required to contribute to the refinement of the proposal or to produce draft material for the thesis. The oral examination was subsumed by the proposal defense to a panel of academics within the School.

The structure reflected the hegemony of academic values and criteria relative to the world of professional practice (Lunt, 2011). Candidates regarded as "expert practitioners" were required to deploy that expertise in service of their induction into academic forms of knowledge, achieving required levels of academic performance in the taught components to progress to the research phase. The thesis, comprising two thirds of the program at 70000 words is externally assessed by three independent external examiners, one of whom may be a professional practitioner. Doctoral graduates are expected to develop a critical perspective towards their professional practice and milieu, and the research skills to conduct defensible inquiry in seeking solutions to professional problems. In this respect, the program differs from the explicit CPED agenda "to prepare educators for the application of appropriate and specific practices, the generation of new knowledge and for the stewardship of the profession" (CPED, 2012b). Equally, despite its research focus, the program does not overtly prepare graduates for an academic post (Sweitzer, 2009), although this may be an outcome.

Students considered that the revised structure provided them with specific and relevant teaching; that it supported development of their research skills; and that it provided material directly relevant to their research study. Even the "defense" came to be seen as supportive, confirming the judgment of their supervisors that their project was viable and academically respectable. Students considered that their expectations for "real research" - relevant to their professional or personal interests, and recognized as a formal doctoral research degree - had been met. Thus, the revised EdD program was congruent with Seddon's (2000) argument that teaching should scaffold and induct the learner into important knowledge foundations and ways of knowing (p.12), and that academic knowledge production should be characterized by intellectual rigor and discipline sustained throughout the work (p. 13).

The new structure was easily transferable to the transnational context. The challenge was to provide appropriate supervision to the transnational students in an economically sustainable way, which met the expectations of the transnational students selecting the program. 


\subsection{Transnational Delivery}

The quality of the operational curriculum was critical to the success of the program, to UWA's concern about its international reputation, and the requirements of the Transnational Quality Strategy framework 2005. Quality of program can be considered to be in the eye of the receiver. Ellis' (1993) perspective that "quality" is that which satisfies or gives value to the customer is reflected in the National Code of Practice (AVCC, 2002, p. 1). Many universities translate the concept as "fitness for purpose" which requires that "the product or service fulfils the customer's needs, requirements or desires" (Lomas, 2001, p.2). A fitness for purpose approach assumes that the customer articulates their needs and expectations clearly to the provider (Rowley, 1995), but some of those desires may not be apparent to customers before they commit to the program. Drawing on Lunt (2002), an analysis of candidates' reasons for selecting the School's EdD program clustered around two of Lunt's Models, shown in Table 1.

\begin{tabular}{|c|c|}
\hline $\begin{array}{l}\text { Extrinsic Professional Continuation } \\
\text { Further development of professional career; } \\
\text { providing new opportunities for diversifying } \\
\text { career options }\end{array}$ & $\begin{array}{l}\text { Intrinsic Personal/Professional Affirmation } \\
\text { Cognitive attention to something interesting develop } \\
\text { meaning or solve a problem; affective - pleasure, } \\
\text { self-esteem. Characterized by intellectual stimulus and } \\
\text { personal fulfillment }\end{array}$ \\
\hline $\begin{array}{l}\text { I was keen to improve/develop my skills for } \\
\text { University teaching and research. } \\
\text { To obtain a better job and to deepen my } \\
\text { knowledge of my field }\end{array}$ & $\begin{array}{l}\text { Personal challenge and is reflective of personal interest } \\
\text { and professional field. } \\
\text { Found the Masters course so intellectually stimulating } \\
\text { that I wanted to continue studying. }\end{array}$ \\
\hline $\begin{array}{l}\text { A doctorate would extend my expertise and I } \\
\text { was eager to do it because I felt ready, } \\
\text { experienced. }\end{array}$ & $\begin{array}{l}\text { I wanted to continue working full time, and enjoy the } \\
\text { flexibility of doctoral-level studies that related to my } \\
\text { work. Also, the reputation for rigor and quality. }\end{array}$ \\
\hline
\end{tabular}

Table 1. Candidates' reasons for selection of program, based on Lunt (2002)

Lunt's other two models (Extrinsic Professional Initiation and Extrinsic Professional Alteration) did not feature in either onshore or offshore students' reasons for choosing the course. Transnational students, particularly, identified other concerns. Pragmatic issues of access and course structure were primary considerations:

- Time-frame of course presentation; ease of access.

- The condensed weekend coursework format allowed me to study whilst working full time.

- The schedule of classes fit my work schedule

- No time was wasted discussing general topics. Instead, on day one itself, we were expected to come in with our research topic and start working specifically on it.

- Writing up chapters as assignments was another positive aspect which ensured that no time was wasted on content areas which were irrelevant to our topic.

- The course program and delivery design fit my plan and expectation for pursuing my doctoral degree. I prefer research writing mode to course work mode.

- Structure of program - specifically its emphasis on research.

The perceived quality of the institution and the School reassured students that their expectations of "quality" were likely to be met:

- International reputation of (University)

- Quality of professional staff in both knowledge and support. Strong collegiality.

- Academic achievement at (University) regarded more highly.

- Because it offers a flexible, strong and very sound research program

- Professional organization, staff and facilities. Excellent reputation and integrity.

- Found the staff at the Department very, very helpful

- Good feedback from previous batches of students also contributed to my choice

- Positive feedback from people who successfully completed programs from this university

- High ranking across universities around the world was another powerful factor-ensures that EdD will be recognized for future employment opportunities.

- Previous knowledge of staff/faculty member. 
These expectations were highly congruent with those reported by Chapman and Pyvis (2005, p.49). Other expectations were not as clearly articulated. For example, expectations and desires about their identity as a student of the university, as a member of a community of practice, or the ways in which their learning styles and cultural practices would be recognized and accommodated (Chapman and Pyvis, 2005, p.43) may be tacit for students new to transnational courses. For providers, "international" may simply mean program delivery in an international or in-country setting. Singaporean Masters students expected that course content would be international, and include examples and readings from a range of international contexts, rather than what they perceived to be an overwhelming orientation to western or European sources (Chapman \& Pyvis 2005, p. 46).

Assumptions about international portability of the EdD were based on expectations that the generic research training was informed by internationally recognized expectations of research that students would adapt or apply to their research projects. In developing their projects and conducting literature searches to conceptualize their studies, they would "internationalize" their own reading. In practice, both assumptions were tested; lecturers needed to broaden their selection of research exemplars, but students too had to become less insular in their selection of readings. The initial problem for some students of limited access to a wide range of readings was overcome by the explosion of academic reference materials available through the internet and the capacity of the university Information Services to provide online access overcame these limitations. Singapore citizens also had access to academic data bases through the National Library of Singapore.

\subsubsection{Selection of Research Topic}

Offshore students submit a brief outline of their proposed research with their application for candidature; unlike onshore students negotiations about feasibility of topics are conducted by email rather than face-to-face. Students in all EdD sites tended to be professionally employed, frequently at middle management levels; EdD candidates who planned to conduct research in their workplaces, or related to their field of employment thought carefully about ways to shape their topic so that it was worthwhile and engaging research, but would not jeopardize their employment prospects. Permission to conduct research and access to sites and personnel were closely connected to how persons with that authority perceived proposed projects. Most students experienced a time consuming and stressful double approval process. At university level, only after the research proposal had been successfully presented could students and their supervisors apply for Human Rights and Ethics approval consistent with requirements of the National Health and Medical Research Council (NHRMC). Only then were they able to apply for permission to conduct research at the proposed site. For government institutions, application had to be made through the relevant Ministry or Department of Education and when that level of permission was achieved, application to the CEO of the specific research site could be made. Clearly, as the application could be rejected or significant amendments required at any of these approval stages, (after the student had invested in four coursework units and the proposal preparation and presentation), care in the initial topic selection and its subsequent refinement was critical in smooth progression to the research phase.

Students in different contexts experienced different cultural challenges. Australian students planning research with Aboriginal groups required additional approval processes, and a community member or sponsor to provide culturally appropriate research guidance. Students in Singapore identified difficulties with socio-political realities of their cultural environment. Research with international students onshore in Australian universities (Ryan \& Hellmundt, 2003; Crew \& Bodycott, 2002) suggests that opportunities to share knowledge and experience, or to promote culturally open attitudes and extensive communication between academics and international students are likely to have positive outcomes for international students. However, Chapman and Pyvis (2005, p. 48), found that the expectation that students would divulge aspects of their private lives produced a discomforting focus on cultural difference. The public discourse of Singapore as a successful multicultural society precluded, on the grounds of cultural sensitivity, discussion which focused on ethnicity, religious or language differences. The tacit etiquette of cultural differences sometimes constrained the selection of research topics. In negotiating and refining their topics, students sometimes struggled to explain why it was not possible or appropriate to ask certain questions, or to gather data in particular ways. Selecting and crafting research topics that reflect students' professional experience and interests, but do not imply criticism of public policy or institutional practices continues to be a challenge. In some respects these difficulties resonate with concerns of Lee et al (2000) about potential conflicts between researchers and their research sites in Mode 2 doctorates. Ethical issues of anonymity and confidentiality for colleagues involved in on-site research, and the challenges of dependent relationships (either for staff in subordinate positions or students whose assessments might be perceived to be threatened, for example) are frequent issues to be resolved. 


\subsubsection{Competing Pressures: Study, Work and Family}

EdD coordinators sometimes characterize their students as "mid-career, mid-life, middle management, and if they haven't had their mid-life crisis before they enroll, they'll have it after", descriptors that resonate wryly with some of the issues identified by Shulman, Golde, Bueschel, and Garabedian (2006, p. 24). Candidates are also likely to experience career change, health problems (their own, or other family members) and have responsibilities for dependent children or ageing parents, particularly if their enrollment extends to six years of part-time study. Thus, students value the compressed delivery as supportive of maintaining work and family commitments while studying. Nonetheless all students reported that time management was a major issue. Maxwell and Shanahan (2000, p. 16) identified "the intensity of candidates' professional workplaces" as one of the contributing factors in slow completion rates. Candidates identified "time poor" stress as a major problem:

I use every single one of my long weekends, annual leave and casual leave and group them together and I try to get away from this place for two weeks or three weeks and then I stay just like a student, to catch up. (Chapman \& Pyvis, 2005, p. 45)

Similarly, onshore students use periods of long-service leave, professional development leave, or unpaid leave at critical times in their research trajectory. Typically such occasions include data collection, if site access is limited to particular times, data analysis (especially students coding large quantities of qualitative data) or in completing the write-up of the penultimate draft. Offshore students sometimes employ leave periods to visit the Perth campus and work intensively with their supervisors. These opportunities create a greater sense of identity with the university, addressing concerns expressed by some students that "it seems strange to get a degree from a university when you never set foot on the campus."

The structure of the coursework units supports satisfactory progression. Because the coursework papers produce draft thesis material, which supervisors encourage candidates to revise as penultimate thesis chapters before commencing data collection, final thesis production is less intimidating.

Despite these strategies, competing demands sometimes become insurmountable. Introduction of the MEd Research Methods as an exit point in the program created a let-out clause for a number of contingencies: failure to meet course grade requirements to proceed to the thesis stage; inability to defend an acceptable proposal; discontinued access to the research site or target population and no suitable alternative available; intervention of personal or career factors. Award of the MEd Research Methods requires successful completion of the coursework units, after which students may apply to take it out at any time. Apart from saving face, the award recognizes what has been successfully accomplished, and may be used for entry or credit with programs offered by the university or other institutions.

\subsubsection{Supervision}

Program coordinators regarded quality supervision as critical in the offshore doctoral program. Past experiences with external $\mathrm{PhD}$ students provided some salutary lessons in the challenges of supervision at a distance. Candidates in both Singapore and Hong Kong were concerned that the School was there for the long haul, and that the program would not be abandoned at some point. Coordinators were aware of some "walking wounded" who claimed to have experienced this in other programs. The coordinators were equally concerned about maintaining and monitoring quality supervision so that students felt supported, but that supervisors did not feel undermined.

Supervisors are assigned as soon as students complete the final coursework paper. Onshore students are advantaged in meeting with academic staff and identifying their own supervisors. Offshore students are allocated supervisors by the program coordinators, who attempt to ensure a good fit, with priority given to the proposed research methods rather than the substantive content. Supervisors are required to work with a group of students to minimize travel and accommodation costs of offshore visits. Only supervisors with a track record of successful supervision are appointed to the transnational program.

Supervisory relationships can be volatile and difficult to maintain; complexities are compounded when supervising at a distance in a cross-cultural environment. Hong Kong doctoral students considered that they had a responsibility to develop good relationships with their supervisors, but differed on how to go about it. Perspectives on contacting their supervisors varied from the inappropriateness of "bothering" their supervisor to being quite happy to initiate contact by email. According to Chapman and Pyvis (2005, p.44) all students expressed the view that they should not harass supervisors with follow-up emails if they did not reply on the first occasion. Supervisors' perspectives differed somewhat, citing students who failed to respond to emails, failed to attend or cancelled scheduled meetings, or did not email draft work when it was required. Alternatively, some 
students (a minority) expected a 24/7 response; without an immediate reply, they would send multiple messages, unwilling to recognize that supervisors had other workload responsibilities, including other research students. None of these issues is significantly different in onshore supervision; the additional strain on the supervisory relationship offshore is the limitation of one face-to-face meeting per semester.

Initially in the offshore programs, coordinators appointed a second supervisor, who met with all students in each cohort in a "policing" role. Visits from this supervisor interleaved visits from the substantive supervisor. The role of the "police person" was a delicate one, intended to give students experiencing difficulties with their supervisor an opportunity to raise their concerns, but also to assist supervisors in managing "delinquent" students who did not respond to emails, or were less productive than required. Their reports were shared with the coordinators and supervisors to manage any necessary intervention. As supervisors gained experience in steering at a distance, the function of the "police person" was reviewed and replaced by an explicit pathway for students' support through referral by the Administrative Officer, to a senior academic with whom the student had no perceived conflict of interest.

Interaction between supervisors and students is substantially by email, as it is for onshore students who live and/or work at considerable distances from the campus. Students email drafts as attached documents; supervisors respond using Track Changes, or by scanning annotated hard copies to return electronically. Location in the same time zone and developments in technology facilitates use of real time conferencing using technology such as Skype or co-authoring software.

\section{Claims of Success}

Reviews of the EdD program presented in this paper began in 1999, before the work of Lunt (2002), Toma (2002) and Shulman et al (2006) or Hargis (2012) was available. After the first cohort of transnational students completed (mid 2008), past and present students were surveyed again. The results presented below suggest that the program operates successfully onshore and offshore in the contexts in which it has been offered.

\subsection{Indicators of Student Satisfaction}

Student satisfaction is a key priority. Although all units are taught in compressed mode, the principles of focused critical engagement dictate small classes with high levels of interaction, as students engage with the generic research approaches and apply them to their own research topics. The size of each cohort is constrained by the challenges of providing excellent supervision at a distance. Consequently, recruitment relies predominantly on student satisfaction, word of mouth and one or two promotional presentations in each context. The 2008 survey solicited open-ended anonymous perspectives on course experiences. Seventy six complete returns were received (39.47\% return rate). The Course satisfaction component asked respondents to rate 11 items on a four point scale, with an additional alternative of Not Applicable. As Table 2 indicates, there was a high level of satisfaction on the pre-determined items. 
Table 2. Results of survey of all EdD students, July 2008

Scale: SD, Strongly Agree; D, Disagree; A Agree; SA, Strongly Agree; NA, Not Applicable n=76

\begin{tabular}{|c|c|c|c|c|c|c|}
\hline Survey Item & SD & D & $\mathbf{A}$ & SA & NA & \\
\hline \multirow{2}{*}{$\begin{array}{l}\text { I was satisfied with the initial responses to inquiries about the EdD } \\
\text { program at (School) }\end{array}$} & 0 & 0 & 28 & 47 & 1 & Freq \\
\hline & 0 & 0 & 36.8 & 61.8 & 1.3 & $\%$ \\
\hline \multirow[t]{2}{*}{ The course materials met my expectations } & 0 & 5 & 29 & 41 & 1 & Freq \\
\hline & 0 & 6.6 & 38.2 & 53.9 & 1.3 & $\%$ \\
\hline \multirow[t]{2}{*}{ The teaching during course work met my expectations } & 1 & 3 & 31 & 41 & 0 & Freq \\
\hline & 1.3 & 3.9 & 40.8 & 53.9 & 0 & $\%$ \\
\hline \multirow[t]{2}{*}{ There was adequate academic support during the program } & 2 & 7 & 20 & 45 & 2 & Freq \\
\hline & 2.6 & 9.2 & 26.3 & 59.2 & 2.6 & $\%$ \\
\hline \multirow{2}{*}{ The feedback on my course work was prompt } & 2 & 3 & 16 & 54 & 1 & Freq \\
\hline & 2.6 & 3.9 & 21.1 & 71.1 & 1.3 & $\%$ \\
\hline \multirow{2}{*}{$\begin{array}{l}\text { The feedback on my academic papers was helpful in progressively } \\
\text { modifying my work }\end{array}$} & 2 & 0 & 18 & 52 & 4 & Freq \\
\hline & 2.6 & 0 & 23.7 & 68.4 & 5.3 & $\%$ \\
\hline \multirow[t]{2}{*}{ Supervision was available when I needed } & 1 & 2 & 17 & 53 & 3 & Freq \\
\hline & 1.3 & 2.6 & 22.4 & 69.7 & 3.9 & $\%$ \\
\hline \multirow[t]{2}{*}{ Supervisors provided timely and helpful feedback on my thesis } & 1 & 3 & 10 & 55 & 7 & Freq \\
\hline & 1.3 & 3.9 & 13.2 & 72.4 & 9.2 & $\%$ \\
\hline \multirow[t]{2}{*}{ I would recommend this program to friends and colleagues } & 2 & 0 & 17 & 56 & 1 & Freq \\
\hline & 2.6 & 0 & 22.4 & 73.7 & 1.3 & $\%$ \\
\hline \multirow[t]{2}{*}{ My career prospects have improved as a result of my EdD studies } & 2 & 5 & 28 & 24 & 17 & Freq \\
\hline & 2.6 & 6.6 & 36.8 & 31.6 & 22.4 & $\%$ \\
\hline \multirow[t]{2}{*}{ My EdD studies have improved my professional work } & 0 & 3 & 23 & 45 & 5 & Freq \\
\hline & 0 & 3.9 & 30.3 & 59.2 & 6.6 & $\%$ \\
\hline
\end{tabular}

Respondents were asked to identify four main strengths of the course. These data were clustered in five categories, with sample comments ranked by frequency as shown in Table 3.

Table 3. Program strengths identified by student participants $n=76$

\begin{tabular}{ll}
\hline Category & Comments \\
\hline $\begin{array}{l}\text { Quality } \\
\text { of course }\end{array}$ & $\begin{array}{l}\text { Pragmatic aspects: flexibility; accessibility; manageable study/work balance } \\
\text { Structure: logical sequence of units; scaffolded units leading to proposal and thesis development } \\
\text { Content: focused, practical, useful; promoted generic skills; comprehensive coverage; balanced; opportunities to } \\
\text { present work }\end{array}$ \\
$\begin{array}{l}\text { Quality } \\
\text { of teaching }\end{array}$ & $\begin{array}{l}\text { Knowledgeable and enthusiastic professors; diversity of teachers; breadth of knowledge of lecturers; use of } \\
\text { Quality } \\
\text { of supervision }\end{array}$ \\
$\begin{array}{l}\text { Research } \\
\text { environment }\end{array}$ & $\begin{array}{l}\text { Diverse background of other students; high standards and expectations; strong researchers; collegiality of staff } \\
\text { and students; networking; recognition of student expertise; concern for equity }\end{array}$ \\
$\begin{array}{l}\text { Quality } \\
\text { of management }\end{array}$ & $\begin{array}{l}\text { Accessibility of staff (administrative and academic); speedy response to requests; supervision problems resolved } \\
\text { quickly }\end{array}$ \\
\hline
\end{tabular}


A small number of adverse comments was noted. Two related to greater choice and earlier allocation of supervisors; two identified need for better information about university procedures and for speedier turnaround of thesis results.

High congruence was evident between the rating scale results and the strengths identified by respondents. A section for open comments was also provided; these comments were clustered according to Lunt's (2002) categories, as shown in Appendix 1.

\subsection{Propositions}

Data presented above generated several propositions about the transnational Doctor of Education program offered by the School.

Proposition 1: Students select the program on the basis of:

- The international reputation of the university, the School and the program

- Pragmatic reasons associated with access and flexibility of the program and its compatibility with their professional workload

- A competitive market price and payment structure

Proposition 2: Students attribute their success in the program to:

- The structure of the course which scaffolds students' development through the course units to the proposal development, research process and thesis writing

- The content of the course which provides them with the necessary skills and competencies to complete successfully

- The quality of teaching and supervision offered by the academic staff

- The responsive administrative support offered by the program administrator and coordinators

Proposition 3: Students value the course because:

- It meets their needs for Intrinsic Personal/Professional Affirmation in following their own research interests leading to self actualization and professional affirmation

- It fulfils their expectations of Extrinsic Professional Continuation in terms of professional development, improved professional recognition and possible enhancement of employment prospects.

- They experience some Extrinsic Professional Alteration, gaining enhanced skills and competencies applicable in their professional roles, new perspectives on their professional fields and models of mentoring applicable in their leadership roles.

\subsection{Benefits for the Program}

Substantial benefits accrued to the program. Streamlined program design and more specific articulation of links between coursework units improved the quality of the program. Production of support materials for the offshore cohorts improved the quality and consistency of teaching materials and other resources for onshore students. Although they are notionally "local", their workplace commitments frequently inhibit attendance on campus and physical access to the libraries.

"Internationalizing" the program has broadened the experience of academics teaching and supervising in both programs. They are able to offer students examples of proposals designed for Perth, Hong Kong or Singapore environments, to offer perspectives on the challenges of research in different contexts to which they otherwise would not have had access. As the offshore students complete, their theses are available to onshore students. The focus on research design taken in the coursework teaching encourages students to review theses with relevant designs; although the substantive content may not be applicable to their studies, they do broaden their understanding of research issues in other contexts.

\subsection{Outcomes for School}

The offshore EdD program has run for ten years in two different contexts with three different partners and accepted ten cohorts of students. The Hong Kong program proved to be the highest risk. Nine of the original 23 candidates were unable to continue for financial reasons based on the impact of terrorism (9/11 in New York), SARs and avian flu on the economic climate in Hong Kong, also reflected in the reduced numbers in the following three cohorts in Hong Kong. Overall, 11 candidates withdrew, 1 was excluded, 1 deceased and 15 applied to graduate with the Masters of Educational Research Methods. Currently, 39 students remain in the thesis phase, and a new cohort of 24 students has commenced in Singapore. Table 4 presents the completions for all doctoral programs in the School since 1997, when the first EdD student completed. 
Enrolments and completions in the transnational EdD programs over 7 years of complete data outweigh the onshore EdD completions over 15 years. Compared with the $\mathrm{PhD}$ in the same time period, the total number of EdD completions is greater (136), and the average per annum is greater (9.06). In the preceding 26 years, a further $65 \mathrm{PhD}$ students completed, for an overall program completion of 147 candidates in 43 years or an average of 3.28 pa for the program. Based on these data, it is clear that of the two doctoral programs offered in the School, the Doctor of Education could be considered the more successful, but only because of the transnational program. Comparison of completions in the onshore programs suggests that the $\mathrm{PhD}$ is still the more popular degree.

Table 4. Comparison of domestic and transnational doctoral completions

\begin{tabular}{|c|c|c|c|c|c|}
\hline Year & $\begin{array}{l}\mathrm{PhD} \\
\text { Onshore }\end{array}$ & $\begin{array}{l}\text { EdD } \\
\text { Onshore }\end{array}$ & $\begin{array}{l}\text { EdD } \\
\text { Hong Kong }\end{array}$ & $\begin{array}{l}\text { EdD } \\
\text { Singapore }\end{array}$ & $\begin{array}{l}\text { All EdD } \\
\text { programs }\end{array}$ \\
\hline 1997 & 3 & 1 & & & 1 \\
\hline 1998 & 7 & 0 & & & 0 \\
\hline 1999 & 5 & 5 & & & 5 \\
\hline 2000 & 4 & 3 & & & 3 \\
\hline 2001 & 5 & 4 & & & 4 \\
\hline 2002 & 4 & 3 & & & 3 \\
\hline 2003 & 5 & 4 & & & 4 \\
\hline 2004 & 5 & 3 & & & 4 \\
\hline 2005 & 7 & 3 & 5 & & 8 \\
\hline 2006 & 3 & 6 & 6 & 10 & 22 \\
\hline 2007 & 8 & 4 & 6 & 6 & 16 \\
\hline 2008 & 8 & 2 & 5 & 7 & 14 \\
\hline 2009 & 5 & 2 & 3 & 12 & 17 \\
\hline 2010 & 6 & 8 & 1 & 13 & 22 \\
\hline 2011 & 7 & 4 & 1 & 6 & 11 \\
\hline 2012* & & 1 & & 1 & 2 \\
\hline Total & 82 & 54 & 27 & 55 & 136 \\
\hline Av p.a. & 5.4 & 3.6 & 3.86 & 9.16 & 9.06 \\
\hline
\end{tabular}

*Incomplete data

There are clear differences in both the enrolment and completion rates between the offshore and onshore EdD candidates. In Australia, education bureaucracies offer little promotional or financial reward for completion of a doctoral degree; students are still motivated more by personal interest (Refer to Appendix 1).

In both offshore locations, students regarded successful completion as financially rewarding and career enhancing and were thus motivated to enroll, and to complete as efficiently as possible. Semester fees beyond their first four years provided a financial incentive for timely completions. Onshore candidates with Australian citizenship or permanent resident (PR) status do not pay fees; they are funded by the federal government for up to eight years of part time study through the research training scheme (RTS), so there is little incentive to complete early. Onshore students are also constrained by regulations which do not allow them to complete their coursework and defend their proposal in less than two years. Time lines negotiated with offshore partners allow candidates to progress through the coursework and defend proposals in eighteen months. These differences may contribute to the differences in the completion times of the two groups.

\subsubsection{Resilient Partnerships}

The offshore program of the School (as distinct from the offshore EdD) is in its fifteenth year. Three partnerships begun at Masters level extended to the EdD program, in which recruitment has gone beyond a simple flow-through of Masters completions. Two partnerships are on-going while one terminated by mutual agreement, without any damage to students. Partnership resilience has survived potential threats created by SARS, international terrorism and outbreaks of avian influenza. Relationships have developed sufficient trust for frank discussions about managing adverse economic fluctuations, changes in government regulations and possible alternative strategies for programs.

The offshore program has enhanced School visibility and its reputation in the region. The transnational doctoral 
graduates form a significant group of alumni who increasingly hold influential positions in their own countries. They have become supportive contacts in negotiating future opportunities, particularly as countries in the region seek to internationalize their educational programs. The success of the transnational programs may have contributed to the increased numbers of international students seeking places in research programs onshore. Their presence and participation in the School has boosted doctoral completions in the $\mathrm{PhD}$ program and contributed to the cultural breadth of the School as a whole.

\subsubsection{Financial Advantage}

Offshore earnings have subsidized the onshore activities of the School since 1997. At any time in the past fifteen years, more Masters by coursework and major paper students have been enrolled through the offshore program than onshore. The income has subsidized onshore programs, supported academic funding for conferences, prevented attrition of academic staff and funded liabilities for study leave and long-service leave entitlements.

In the Masters programs financial advantage accrues from student fees alone. Doctoral fees are reviewed regularly and increased by the minimum of consumer price index (CPI), but they are set to cover the costs of program delivery plus a small profit margin to meet unforeseen contingencies. In addition to the income from fees, the federal government contributes a financial reward for successful research completions, rising from initially, AUD25 000 per student to currently AUD27 500. Payments begin two years after students complete, and are spread over three years, in a "smoothing" effect, which makes income more predictable. The financial impact of the transnational completions is shown in Table 5.

Table 5. Financial return from transnational EdD programs 2005-2011

\begin{tabular}{|c|c|c|c|}
\hline Hong Kong & Singapore & & All Offshore EdD Programs \\
\hline Nett profit on delivery & Nett profit on delivery & Total net profit on delivery & Completion funds \\
\hline AUD 15244 & AUD 513805 & AUD 542049 & AUD 1935000 \\
\hline
\end{tabular}

With 39 students remaining in the thesis phase and a further 24 new enrolments, the most optimistic projection for future completion funds is AUD1 732500 over the next ten years. This line of income ensures financial viability of the School while new onshore professional programs become strongly established. As these new programs are all pre-service teacher education programs and funded at marginal rates by the federal government, it is likely that the School will continue to depend on the transnational program, unless an alternative strong income stream can be found.

\section{Potential Threats to Program Sustainability}

\subsection{Academic Sustainability}

Academic sustainability of the program relies on quality teaching and supervision. Work in the offshore program is not included in School workload, but undertaken as paid consultancy. Academics engage in the programs in addition to maintaining the required onshore workload. The work is optional; no staff member is required to undertake it. Motivation to do so appears to be a complex mix of genuine interest, professional development, opportunities for research and financial incentive. A stable core of increasingly senior (and ageing) staff have maintained the program for ten years, with one or two new staff joining in the past three years.

Because higher numbers of supervisors are required, and the work is paid as consultancy, additional affiliated lecturers (usually retired academics) are employed. Strong selection criteria apply: no conflicts of interest; very high teaching and/or supervision competencies and performance; sensitivity and experience in cross-cultural work. The balance between full-time School staff and affiliated academics is important. Transnational students and partners check out credentials of new personnel on the website; partnerships require that teaching and supervision is by School staff, and maintaining quality is a key issue.

Three threats to academic sustainability are evident. First, the ageing workforce of the transnational program cannot sustain the demands of offshore teaching and supervision indefinitely. Second, the shift in School focus occasioned by expansion of the professional MTeach programs onshore required employment of academics specifically to support pre-service professional teaching; currently they have less experience and commitment to teaching and supervision in higher degree research and their work structures are not readily compatible with it. Without recruitment of some full time academics with both experience and interest in higher degree research teaching and supervision, the program may have to be phased out. The third potential threat is from the 
University level. In the Courses 2012 Review, including research methods coursework units in the $\mathrm{PhD}$ was considered. If this occurs, the most significant point of difference between the $\mathrm{PhD}$ administered by the Graduate Research School, and the Doctor of Education administered within the School of Education may be lost, diminishing viability of the Doctor of Education program.

\subsection{Economic Sustainability}

Maintaining market share is clearly significant in any enterprise. Competition in Hong Kong and Singapore initially came from other international providers and Australian universities. Location within the region and within the time zone permitted competitive pricing and reduced staff wear and tear. Changes to regulations in both Hong Kong and Singapore allowed local providers to enter the market. This had an impact in Hong Kong, particularly at the Masters level, where universities can offer courses directly relevant to local professional development needs more cheaply. In 2006, regulation change in Singapore encouraged local universities to offer part-time Masters programs; more recently the National Institute of Education has offered a Doctor of Education program.

Maintenance of market share is clearly linked to profit margins. Capacity to contain fees to a sustainable level is influenced by costs (travel and accommodation) and the numbers of students enrolled in each cohort. Declining enrolments, rising costs and resistance to fee increases reduces the capacity of a program to pay for itself; this stage was reached in Hong Kong in 2006, leading to closure of the Doctor of Education program. Maintaining programs with small profit margins is viable only with the federal financial reward for successful completions.

There are real and prospective impacts from globalization, internationalization and regionalization. Singapore is increasingly a significant regional education provider. Sanderson (2002) asserted that Singapore, by necessity and design, was on the verge of creating a unique "hub" of international education which would emerge as a significant competitor for countries like Australia, New Zealand, the UK, USA and Canada not only in ASEAN countries, but across the globe (p. 97). The Singapore government subsidizes international students' polytechnic studies in return for a two year working bond in Singapore (Sanderson, 2002, p. 93); Ng (2011, p. 265) noted extension of the scheme to university students. Two universities, NUS and NTU, in working towards World Class University (WCU) status, announced that they had met their targets of $20 \%$ enrolment of international students by 2000. Under the WCU program, the Singapore Government strategically invited world top universities to operate education and research programs (Yonezewa, 2007; $\mathrm{Ng}, 2011$ ), frequently jointly with existing Singaporean universities, initially at postgraduate levels. Gopinathan (2007, p. 65) argued that Singapore's actions in a climate of global entrepreneurialism were "responses of a strong state acting with a view to strengthening the local and the national in order to deal better with the regional and international". Mok (2007, p. 8) concurred with the view that universities in East Asia have begun to shift their paradigms to include a third mission of promoting economic and social development, and concluded that "pursuit of academic entrepreneurship and the transformation towards the "entrepreneurial university' have started in East Asia". Huang (2007, p. 244) extended this argument, observing that emerging countries and some special regions such as Singapore and Hong Kong engaged in both importing HE from Australia, the UK and USA, but exporting HE to other Asian countries.

An emerging trend in globalization of $\mathrm{HE}$ is consortia of universities offering access to degrees such as The Intercontinental Master of Education in Adult Learning and Global Change. The program, shared between four contributing universities, offers a global perspective on learning in a cross-cultural environment (The Centre for Adult and Continuing Education (CACE), University of the Western Cape). Hargis (2012) reports on a proposal to establish a doctoral degree on Global Education and Leadership for academic teachers, comprising six coursework units and a dissertation to be offered on host campuses in Africa, Asia, Oceania and the Middle East coordinated by the University of the South Pacific. Directed specifically at academic teachers, this may be the first program to target global tertiary education.

The Doctor of Education, a very successful program for the School, is thus open to threats on a number of levels. Should the program become unsustainable, the adverse effects of the closure would go beyond financial losses to the School; it would impact on the quality of remaining programs and the international visibility and standing of the School.

\section{Conclusion}

This paper presented a case study of a single School offering a transnational Doctor of Education program within its geographic region. Both the impetus for and the shape of the program were influenced by policies at the national and local levels. The success of the initiative can be attributed to robust international partnerships, the quality of both the program and the staff who contributed to it and the determination of candidates who enrolled 
in it. Despite the success claimed for the program, pressure within the university, and wider challenges of regionalization, internationalization and globalization offer real threats to its long-term future. The projected financial consequences for the School offer an illustration of the dangers in over-reliance on international marketing of programs identified by the University of Sydney (The University of Sydney, 2011, p. 16.).

\section{References}

Australian Government. (2007). National Code of Practice for Registration Authorities and Providers of Education and Training to Overseas Students (The National Code 2007). Canberra: Department of Education, Science and Training (DEST). Retrieved from https://www.aei.gov.au/Regulatory-Information/Education-Services-for-Overseas-Students-ESOS-Legislati ve-Framework/National-Code/Documents/National_Code_2007_pdf.pdf

Australian Government. Education Services for Overseas Students (ESOS) Act. Canberra: Department of Industry, Innovation, Science, Research and Tertiary Education (DIISRTE).

Australian Government. International Student Data. Australian Education International. Retrieved from https://www.aei.gov.au/research/International-Student-Data/Pages/default.aspx

Australian Qualifications Framework Council. (2011). Australian Qualifications Framework. South Australia: AQF Council Ministry Council for Tertiary Education and Employment. Retrieved from http://www.aqf.edu.au

Australian Vice-Chancellors' Committee (AVCC). (2002). Code of Ethical Practice in the Provision of Education for International Students by Australian Universities. Canberra : Australian Vice-Chancellors' Committee.

Banks, M., \& Kevatt, P. (2009). The changing fortunes of Australian TNE. Paper presented at the Australian International Education Conference, Sydney, NSW. Retrieved from http://www.aiec.idp.com

Chapman, A., \& Pyvis, D. (2005). Identity and social practice in higher education: Student experiences of postgraduate course delivered "offshore" in Singapore and Hong Kong by an Australian University. $\begin{array}{llll}\text { International Journal of Educational Development, } & \text { 25(1), }\end{array}$ http://dx.doi.org/10.1016/j.ijedudev.2004.05.003

CPED Initiative. (2012a). An Inter-Institutional Discussion about Reclaiming the Education Doctorate. Retrieved from http://www.cpedinitiative.org/design-concept-definitions

CPED Initiative. (2012b). About CPED-The Carnegie Project on the Education Doctorate. Retrieved from http://cpedinitiative.org/about

Crew, V., \& Bodycott, P. (2002). "Why does she call me 'Darling'?"-Culture and affect in overseas language immersion programs. In Y. C. Cheng, K. T. Tsui, K. W. Chow, \& M. C. M. Mok (Eds.), Subject teaching and teacher education in the new century: Research and Innovation (pp. 409-438). Hong Kong: The Hong Kong Institute of Education, Kluwer Academic.

Davis, D., Olsen, A., \& Bohm, A. (Eds.). (2000). Transnational education providers, partners and policy: Challenges for Australian Institutions Offshore. Canberra: IDP Education Australia.

Ellis, R. (1993). Quality Assurance for University Teaching. Buckingham: Open University Press.

Gopinathan, S. (2007). Globalisation, the Singapore developmental state and education policy: A thesis revisited. Globalisation, Societies and Education, 5, 53-70. http://dx.doi.org/10.1080/14767720601133405

Hargis, J. (2012). A doctoral program for the world: Global tertiary education and leadership. International Journal of Instruction, 5(1), 129-140.

Harmon, G. (2005). Internationalisation of Australian Higher Education. In M. Tight (Ed.), International Perspectives on Higher Education Research: Vol. 3. International relations (pp. 205-232). Emerald Group Publishing Limited. http://dx.doi.org/10.1016/S1479-3628(05)03009-1

Huang, F. (2007). Internationalization of higher education in the developing and emerging countries: A focus on transnational higher education in Asia. Journal of Studies in International Education, 11, 421-432. http://dx.doi.org/10.1177/1028315307303919

Knight, J. (2004). Internationalization remodelled: Definition, approaches and rationales. Journal of Studies in International Education, 8(1), 5-31. http://dx.doi.org/10.1177/1028315303260832

Knight, J. (2008). Higher education in turmoil: The changing world of internationalization. Rotterdam, 
Netherlands: Sense.

Lee, A., Green, B., \& Brennan, M. (2000). Organisation knowledge, professional practice and the professional doctorate at work. In J. Garrick, \& C. Rhodes (Eds.), Research and knowledge at work: Perspectives, case studies and innovative strategies (pp. 117-136). London: Routledge.

Lewis, N. (2011). Political projects and micro-practices of globalising education: Building an international education industry in New Zealand. Globalisation, Societies and Education, 9, 225-246. http://dx.doi.org/10.1080/14767724.2011.577273

Lomas, L. (2001). Does the development of mass education necessarily mean the end of quality?. Paper presented at the Sixth QHE Seminar "The End of Quality", 25-26 May, Birmingham.

Lunt, I. (2011). Professional doctorates and their contribution to professional development and careers. Economic and Social Research Council Grant Reference: R000223643. Retrieved from http://www.esrc.ac.uk/my-esrc/grants/R000223643/read

Marginson, S., \& Rhoades, G. (2002). Beyond national states, markets, and systems of higher education: A glonacal agency heuristic. Higher Education, 43, 281-309. http://dx.doi.org/10.1023/A:1014699605875

Maxwell, T. W., \& Shanahan, P. J. (1997). Towards a conceptualization of the doctorate: Issues arising from comparative data relating to the EdD degree in Australia. Studies in Higher Education, 22, 133-150. http://dx.doi.org/10.1080/03075079712331381004

Maxwell, T. W., \& Shanahan, P. J. (2000). Current issues in professional doctoral education in Australia and New Zealand. Paper presented at $3^{\text {rd }}$ International Professional Doctorates Conference, "Doctoral Education and Professional Practice: The Next Generation?", Armidale, NSW.

Mok, K. H. (2007). Globalisation, new education governance and state capacity in East Asia. Globalisation, Societies and Education, 5, 1-21. http://dx.doi.org/10.1080/14767720601133009

Ng, P. T. (2011). Singapore's response to the global war for talent: Politics and education. International Journal of Educational Development, 31, 262-268. http://dx.doi.org/10.1016/j.ijedudev.2010.05.009

Rowley, J. (1995). Student feedback: A shaky foundation for quality assurance. Innovation and Learning in Education, 1(3), 14-20.

Ryan, J., \& Hellmundt, S. (2003). Excellence through diversity: Internationalisation of curriculum and pedgagogy. Paper presented at the $17^{\text {th }}$ IDP International Education Conference, Melbourne.

Sanderson, G. (2002). International education developments in Singapore. International Education Journal, 3, 85-103.

Seddon, T. (2000). What is doctoral in doctoral education?. Paper presented at $3^{\text {rd }}$ International Professional Doctorates Conference, "Doctoral Education and Professional Practice: The Next generation?", Armidale, NSW.

Shulman, L. S. (2005). Signature pedagogies in the professions. Daedalus, 134(3), 52-59. http://dx.doi.org/10.1162/0011526054622015

Shulman, L. S., Golde, C. M., Bueschel, A. C., \& Garabedian, K. J. (2006). Reclaiming Education's doctorates: A critique and a proposal. Educational Researcher, 35(3), 25-32. http://dx.doi.org/10.3102/0013189X035003025

Stella, A., \& Liston, C. (2008). Internationalisation of Australian universities: Learning from Cycle 1 Audits. AUQA Occasional Publications Number, 14. Melbourne: Australian Universities Quality Agency.

Sweitzer, V. (2009). Towards a theory of doctoral student professional identity development: A developmental networks approach. The Journal of Higher Education, 80(1), 1-33. http://dx.doi.org/10.1353/jhe.0.0034

The University of Sydney. (2011). The University of Sydney 2011-2015 Green Paper. Retrieved from http://sydney.edu.au/about/strategy/green_paper/green-paper-whole.pdf

Toma, J. D. (2002). Legitimacy, differentiation, and the promise of the EdD in higher education. Paper prepared at the Annual meeting of the Association for the Study of Higher Education, Sacramento, CA.

Tootell, K. (1999). International students in Australia: What do we know of the quality of their education?. Paper presented at the Australian Association for Research in Education (AARE) Conference, Melbourne.

Waters, J., \& Brooks, R. (2011). International/transnational spaces of education. Globalisation, Societies and 
Education, 9, 155-160. http://dx.doi.org/10.1080/14767724.2011.576933

Yang, R. (2002). University internationalisation: Its meanings, rationales and implications. Intercultural Education, 13, 81-95. http://dx.dio.org/10.1080/14675980120112968

Yonezawa, A. (2007). Strategies for the emerging global higher education market in East Asia: A comparative study of Singapore, Malaysia and Japan. Globalisation, Societies and Education, 5, 125-136. http://dx.doi.org/10.1080/14767720601133561

Ziguras, C. (2011). Global trends and key issues in transnational education. Paper presented at "Excellence in TNE Partnerships for the Future", Kuala Lumpur, Malaysia. Retrieved from $\mathrm{http}: / /$ www.britishcouncil.org/malaysia-excellenceintne-speaker-presentations-ziguras.pdf

\section{Appendix}

\section{Open comments clustered according to Lunt's (2011) categories}

\section{Extrinsic Professional Continuation}

EdD experience has been extremely rewarding, providing me with the tools needed to conduct research, and assisting me to hone my writing skills from an academic standing point.

Difficult to determine how the EdD will influence my career prospects; however, I am confident that it will have a bearing on positions sought.

It's been a wonderful learning journey in my professional development. Having served the EdD helps me to consider joining NIE as an academic staff or to return to Ministry of Education as a specialist in curriculum and instruction.

Greater awareness of Research Methods. Confidence to participate in more research related programmes at workplace.

While this degree has not been of value for my employment it has asserted with status within the wider community and overseas.

The EdD has been a useful and interesting professional experience. Whilst it has yet to lead to a significant promotion, it has certainly broadened the scope of potential employment opportunities. The course has also fostered a deeper interest into educational research as a whole.

\section{Extrinsic Professional Alteration}

Whatever I have learnt from my EdD courses, I can apply directly to my present cultural studies research programme in my school. I am able to conduct workshops to train my teachers on research mentorship and help the curriculum planning division in the Ministry of Education (Singapore) advise on the writing guide for independent studies.

The coursework portion of the EdD provided me with a firm foundation in research methods which has stood me in good stead even now in my professional work.

Has taught me some valuable information like writing research proposals. Has enriched my knowledge especially about research (starting form writing up a proposal, steps taken to do research, research strategies and the thesis writing exercise)

The value for me was a sense of personal achievement and the ability to perform my professional role much more successfully. It contributed significantly to my status in my professional role. My research was very relevant to my role in education - it placed me in the forefront of curriculum development.

I value my assigned supervisor's detailed and always timely feedback on my submitted chapters. This is done regardless of how busy he is! I don't always have an opportunity to be properly mentored. This is one of them. I also learned coaching skills from him-how to present criticism and corrections in the best way.

\section{Intrinsic Personal/Professional Affirmation}

Opportunity to attend forums to experience work of other scholars. Opportunity to research and formalize own view of ongoing educational issues.

Highly valuable experience. Have thoroughly enjoyed the course. It has been challenging and academically stimulating.

The EdD program has offered the only truly valuable professional and intellectual development I require and expect. Without this programme I would probably have returned to the UK. Thank you! 
For me the EdD has been a personally motivating and fulfilling learning experience of the highest quality.

Very rewarding experience. Great professional development

The EdD is a very well-structured program with a great deal of help and support offered to students in the preparation of their research proposals and theses. I have spoken highly of it to other students and colleagues. I very much enjoyed being part of it.

An excellent experience - has given me extra skills and knowledge. Have been very well supported throughout.

Gave me wider breadth of professional theory and practice, and the wisdom I was seeking about wider social perspectives and values. I am enriched, self-actualised, and more confident in expertise.

Self-improvement. Very different and hard time throughout the study period, mainly due to the heavy workload, but still worth to do and really a good experience, highly recommend others to do it.

EdD has been thus far an incredibly empowering experience...I don't feel like I'm a student, instead as the salutation of this letter states "Doctoral colleagues". I feel like I'm conducting research like an independent scientist instead of a student hoping that I'm on the right track. The program recognizes the expertise a doctoral candidate brings to the table and facilitates the flowering of this budding ability and talent in its students building confidence and faith in their capacity to complete the EdD successfully. THANK YOU!! 